\title{
What Factors May Make Flexibility a Positive Thing for
}

\section{Employers and Employees?}

\author{
Mohammad Jasim Uddin (Research Fellow) \\ Bangladesh Institute of International and Strategic Studies (BIISS) \\ 1/46 Old Elephant Road (West of Ramna Thana) \\ Eskaton, Dhaka - 1000, Bangladesh \\ Tel: 88-1815-574-629_E-mail: jasim_biiss@yahoo.com
}

Received: October 27, $2010 \quad$ Accepted: November 25, $2010 \quad$ doi:10.5539/ijbm.v6n4p188

\begin{abstract}
Till to date since the 1980s, whether flexibility is a positive thing for both employers and employees is debated. Even issues responsible to the ambiguity are also debated. This paper attempts to identify some factors or conditions that may make flexibility a positive thing for both employers and employees. This paper reveals that sometimes employers' flexibility questions employees' flexibility. At times, the latter challenges the former. To attain mutual gains, employers should be aware of some factors challenging to employees' flexibility. Employers should reduce institutional complexities existing in their firms. Conversely, both employers and employees should balance their power and ownership. They could accentuate on positive social network ties. In general, employers need to change their attitude and respect to employees' basic demands. By contrast, employees' dynamic attachment with and positive response to their firms are important. Additionally, factors identified as internal and external should effectively be taken into consideration.
\end{abstract}

Keywords: Flexibility, Best capturing indicator, Factor

\section{Introduction}

Since 1980s, flexibility has been an important concept in industrial relations system (Wood, 1989). It has also become an important idea in corporate thoughts based on inflexibilities varied in labor and employment blueprints (Atkinson, 1985). Some argue that flexibility is an indispensable asset to participate in vibrant industrial environment. Others define it in various respects. Atkinson (1985) describes flexibility based on two things: where it occurs and how it is developed (Kalleberg, 2003). Pollert (1987 and 1991) asserts that flexibility cannot be abstracted from its other objects and areas of interests. MacInnes (1987) supports the idea of Pollert. Flexibility has thus rather been an abstract notion (Pollert, 1991). However, the notion has been purchasing importance over the last three decades for both employers and employees (Brodsky, 1994). Now question is what is flexibility for employers and employees? Why do they need flexibility?

Employers claim flexibility owing to various causes. An important cause is deregulation of employment that enables them to fix workforce according to needs (Chung, 2007). It gives them an opportunity to separate workforce into core and peripheral workers (Atkinson, 1984). It also offers employers an opportunity to adjust to workforce absence because of leaves or absenteeism by employing fresh workers. Furthermore, deregulation of employment helps employers to monitor the fresh recruitments before providing workers with long-term employment (Houseman, 2001). In addition to the deregulation of employment, other causes are to vary working hours and to meet labor supply needs (Chung, 2007). By contrast, employees require flexibility owing to several rationales such as maximizing wage, improving job security, finding work-life balance such as reconciling care, increasing labor participation and representation in making decision. Other rationales are enhancing both-way communication between employers and employees, and flexible labor supervision at workplace (Chung, 2007).

Various literature (Ketkar and Sett, 2009; Chung, 2007; Pegler and Knorringa, 2007) show that practice of flexibility offers employers a chance to vary workers and working hours according to needs, and provides employees with secure job, higher wages, fixed working hour and better working condition. Other studies (Kalleberg, 2003; Smith, 1995) that find flexibility as a function of benefits neither for employers nor employees are least documented. On the contrary, there are some evidence (Michie and Sheehan-Quinn, 2001; Gellatly et 
al., 2009; Pudelko, 2005) indicate that flexibility offers various opportunities for employers but for employees, the opportunities are less. The evidence show that introduction of flexibility does not have significant outcomes for workers' benefits, particularly when technological innovations are experienced and executed by employers' unilateral decisions without considering workers' collective voices. The transition deteriorates workers' job quality and security, and increases inequalities between employers' and employees' demands. Whether flexibility is a positive thing for both employers and employees is thus still debated. Even factors or conditions responsible to the ambiguity are also debated (Humphrey, 1994; Martin, 2001; Pudelko, 2005; Gamble et al., 2004). Therefore, the main research question of this study is what factors or conditions may make flexibility a positive thing for both employers and employees? To concentrate on the question, this study needs addressing the following sub-questions: (a) what indicators may best capture flexibility of employers and employees? and (b) what internal and external factors may act to promote a win-win situation on flexibility for both employers and employees?

In dealing with the research questions, this study reviews existing literature, and uses 'analytical narratives', a tool of case study method. While 'analytic' means using of a theoretical framework or setting of theoretical concepts, 'narratives' means using of qualitative evidence (Alston, 2005). A major handicap in this study is dearth of information and consultation of published information materials. Therefore, existing literature have only been enough for providing with a vigilant conclusion on the research questions. The conclusion would provide with important insights for the people interested in the area of flexibility, particularly the industrial policy makers, transnational or multinational companies, the development initiators outside the government, and the employers and the employees as the important development actors.

\section{What indicators may best capture flexibility for employers and employees?}

Based on existing literature (Uddin, 2010; Chung, 2007; Walby, 1989; Hunter et al., 1993; Michie and Sheehan-Quinn, 2001; Gellatly et al., 2009; Delson, 2004; Reilly, 2001; Yanadon and Kato, 2009; Tikos, 2009; Atkinson, 1984 and 1985; Kalleberg, 2003; Pudelko, 2005; Knorringa and Pegler, 2006; Guzman, 2000; Toledo, 2007; Tayeb, 1998) on employers' strategies concerning flexibility and their impacts on employees' flexibility, indicators that may best capture flexibility not only for employers but employees also could be structured under the following framework:

Place Figure 1 here

The potential best capturing indicators of flexibility for employers and employees underlined in Figure 1 could also be framed under the following equations:

$$
\begin{aligned}
& \mathrm{F} m r=f(v l e, v w h, m e i w) \\
& \mathrm{F} m e=f(j s, r t, l w, w h, p l, w c, r l, m s, w s, w p, m u) .
\end{aligned}
$$

Where, Fmr is flexibility for employers, Fme is flexibility for employees, vle is variation in labor employed, $v w h$ is variation in working hours, meiw is mode of employee involvement to workplace, $j s$ is job security, $r t$ is rate of turnover, $l w$ is level of wages, $w h$ is working hour, $p l$ is participation level, $w c$ is way of communication, $r l$ is representation level, $m s$ is mode of supervision, $w s$ is working situation, $w p$ is working pressure, and $m u$ is mode of unionism. Factually, $p l, w c, r l$ and $m s$ can together be represented as $R s$ (relations between employers and employees), whereas $w s$ and $w p$ can together be represented as $w e$ (working environment). Therefore, equation (II) can be rewritten as

$$
\mathrm{F} m e=f(j s, r t, l w, w h, R s, w e, m u) .
$$

Debate on defining flexibility and characterizing indicators or determinants of flexibility for employers and employees may be differed from firm to firm in a developed or developing country. But existing literature suggest that independent variables included in equations (I) and (II) or (IIa) may likely be the best capturing indicators of flexibility for employers and employees respectively to observe whether practice of flexibility produces identical outcomes for the both parties. Now essence of studying whether flexibility offers identical benefits for employers and employees is to find out some factors challenging to flexibility for the both sides and thereby facing the challenging factors.

\section{Whether flexibility offers identical benefits for both employers and employees: reviewing existing literature}

A study of Chung (2007) on some EU companies reveals that variance of flexibility for employers are smaller than that for employees. This means that 'there might be larger cross-national differences between the arrangements that facilitate workers' needs than that facilitates needs of the establishments' (Chung, 2007, p. 
273). Despite the fact, there is an argument that flexibility is entirely for employers. This is owing to 'increased level of job insecurity' (Chung, 2007, p. 246) that workers usually face from diverse flexibility measures exercised by employers. On the other hand, Kalleberg (2003, p. 156) in a study shows that 'employers often are benefited from adopting flexible working practices and employment systems'. He also reveals that 'employers adopting high performance work practices often experience improvements in productivity and performance, are able to save labor costs by using temporary and part-time workers, and thus enjoy greater profits' (Kalleberg, 2003, p. 156). Furthermore, he demonstrates that flexible working practices offer employers an opportunity to sub-contract or outsource supplementary activities that facilitates employers to concentrate on their core competences and consequently to utilize their resources more competently.

Efforts to achieve flexibility have dark sides for both employers and employees. The dark sides of flexibility are uncertainty and imbalance of power. Efforts of employers to enhance flexibility are directed to 'increased segmentation of workforce into core and periphery components, creating a division between organizational insiders and outsiders' (Kalleberg, 2003, p. 156). By contrast, efforts of employees are directed to have balance of power, voice, participation, efficiency, security and trust to address a positive understanding on flexibility. Then a basic question is to what extent trust is likely to play a role to have a mutual understanding (on the efforts), which seems usually asymmetrical. It is argued in labor studies that 'fundamental asymmetries in employment and industrial relations imply that labor rights improvements, especially those based on trust, may not be consistent with flexibility requirements in global production networks' (Knorringa and Pegler, 2006, p. 472).

Generally a call for 'more flexibility at a firm level is passed on to workers in terms of more insecure and precarious labor conditions and it is here that labor studies seriously question the suggestion that trust is likely to emerge in more flexible employment relations' (Knorringa and Pegler, 2006, p. 473). Instead of anticipating reciprocal trust to actually offer an important drive 'to quality and productivity improvements, it seems more likely to assume that most workers simply work harder because they are afraid to lose their job' (Knorringa and Pegler, 2006, p. 473). On the other hand, there is also inadequate 'evidence to suggest that many production workers have a commitment, allegiance or trust to their employers as a result of new production regime' (Pegler and Knorringa, 2007, p. 41). Therefore, employment relations continue just based on 'triple C' - consent, control and conflict. Permanent workforce may have better employment conditions, but they are seemed to be decreased proportionally. This is because of further outsourcing by employers through employing short-term workforce. Picture in general 'is one of fewer core workers at global level and more differentiation through various layers within firms, local subcontracting arrangements and international relocation of economic activities' (Knorringa and Pegler, 2006, p. 473). Therefore, International Labor Organization (ILO) with its decent work agenda asserts that 'flexibility may not be helpful to building trust within employment relations between employers and employees' (Knorringa and Pegler, 2006, p. 473).

Discussion aforesaid may confuse one: is flexibility good for both employers and employees? Or, does flexibility offer identical benefits for the both parties? Looking at an auto plant in the US, Graham (1994, pp. 123-151) shows that practice of flexibility 'reinforces unequal power relations between workers and management'. Therefore, workers find them susceptible to intensified job. A joint study of Taylor et al. (1994, pp. 196-228) on an electronic firm in Britain also finds workers insecure since employers 'rely on labor turnover as a form of numerical flexibility'. On the other hand, Dedoussis and Litter (1994, pp. 175-195) in their joint study on eight manufacturing firms in Australia reveal that 'big firms disseminate information to employees to enable them to perform their duties effectively rather than to allow them to have significant involvement in decision making'. Therefore, benefits emerged from practice of flexibility tend towards employers. Such outcomes are also available in a joint study of Rinehart et al. (1994, pp. 152-174) on a unionized auto assembly plant in Canada, where workers have a voice but not a vote.

There are also some studies indicating that practice of flexibility offers mutual benefits for both employers and employees. A joint study of Gleave and Oliver (1990) on some manufacturing firms in Britain and the US demonstrates that flexible working practices provide employers with higher levels of productivity and employees with job security. William et al. (1999) in their joint study on some manufacturing subsidiaries in Australia reveal that considerable use of flexible work practices offers employers an opportunity of recruiting varied workers, and employees a high level of job security and persistent multi-tasking. Therefore, debate, based on existing literature, continues on whether flexibility offers positive-negative or positive-positive benefits for employers and employees. There is also a debate on factors that may challenge flexibility for both employers and employees. 


\subsection{Factors challenging to flexibility for employers and employees}

A set of literature shows that benefits of flexibility for employers and employees are varied owing to some underlying causations or factors. A study of Humphrey (1994) argues that difference in management structure, ability to introduce new technique or technology and sectoral competition challenges reciprocal (positive-positive) benefits of flexibility. On the other hand, Martin (2001, p. 95) in his study asserts that 'impact of flexibility is highly contingent upon concrete social relations in which a transition takes place at the level of particular work sites and particular local and regional agglomerations of firms (sectors, clusters, and chains)'. He states that 'highly varying impacts of flexibilization on systems of worker rights and collective representation in a workplace stem from distinct nature of transition mode to flexibility in different subnational settings' (Martin, 2001, p. 95). A fundamental justification 'for contrasting transition modes towards high labor flexibility is that capacity of firms and worker representatives to transcend zero-sum conflicts over flexibility and forge innovative new practices hinges upon character of social network ties in which, together and separately, they are embedded at the time when exogenous pressures for greater flexibility are experienced (Martin, 2001, p. 95). Such ties condition their styles of communication, behavior, and interaction as well as informational and other resources available to them. Therefore, causations or factors challenging to flexibility for both employers and employees are focused mainly on characteristics of transnational firms placed in diverse local and national locations.

Other set of literature identifies some triggering factors or causations challenging to flexibility. Pudelko (2005, $\mathrm{p}$. 2050) in his study reveals that outcomes on flexibility for employers and employees are varied owing to 'inadequate labor laws and regulations, lack of contractual agreements with unions, and limited participation rights in context of works councils'. On the other hand, a joint study of Gamble et al. (2004) shows that low-trust and low-commitment human resource management (HRM) policies and practices are problematic to have mutual flexibility. Other factors challenging to flexibility include workers' inadequate involvement to and limited career opportunities at workplace, limited information flows from bottom, lack of appraisal and performance assessment, undefined company ownership, and finally limited, top-down and one-way communications between employers and employees (Gamble et al., 2004). These factors make work organization insecure, fragmented and 'Taylorized' for employees. Therefore, industrial societies in all over the world have given considerable emphasis on looking for some factors or conditions that may make flexibility a positive thing for both employers and employees.

\section{Factors making flexibility positive for both employers and employees: a review of internal and external factors}

Various literature put emphasis on some general factors that may make flexibility a positive thing for both employers and employees. In their joint study, Elger and Smith (1994) accentuate on positive social network ties, removal of institutional complexities, and integration of firm to employees. On the other hand, Purcell et al. (1999) in their joint study stress on balancing power and ownership, participation and understanding between employers and employees. Furthermore, Martin (2001) emphasizes on increasing competence of firms and worker representations. Besides, Pudelko (2005, p. 2050) draws attention to 'the extent of labor laws and regulations, contractual conformities with trade unions, and partaking rights in regards to works councils'. These literal evidence indicate that list of general factors can be asymmetric. Therefore, categorizing some specific factors such as internal and external factors that may act to promote a win-win situation on flexibility for both employers and employees is important.

\subsection{Factors (internal and external) to promote a win-win situation on flexibility}

There are inadequate literature indicating a clear separation of internal and external factors that may act to promote a win-win situation on flexibility. Based on existing literature, this study identifies some factors that might be treated as internal and external. Changing perception of flexibility, making mutuality in work, developing trust between employers and employees, and introducing new labor laws beneficial to the both parties may be considered as internal factors (Chung, 2007; Reilly, 2001; Zhang, 2008). Making flexibility a positive thing through transferring management practices may also be considered as an internal factor (Stehle and Erwee, 2007; Guzman, 2000). By contrast, developing role of trade unions, civil society organizations (CSOs), and bringing initiatives of corporate social responsibility (CSR) to light may be considered as external factors (Smith, 1995; Anner, 2007; Pegler, 2001; Pegler and Knorringa, 2007; Blowfield, 1999; Barrientos et al., 2003; Shaw et al., 2006; Knorringa and Pegler, 2006).

\subsubsection{Internal factors}

First, it is important to change perception of flexibility (i.e., flexibility is entirely for employers). Perception should focus on mutuality. Mutual flexibility may ensure needs or security of both employers and employees. 
Second, developing trust between employers and employees is very essential. Trust may possibly be secured if '(i) employees believe that managers will fulfill their side of any bargain, and vice versa, at least in so far as it is within their power to do so; (ii) neither side expects other to deceive them by giving misleading, untruthful, incomplete or partial information; (iii) employees especially, but also managers to a lesser extent, believe that other party has competence to deliver; and (iv) both parties expect that their needs will be respected, that they will not be deliberately harmed' (Reilly, 2001, p. 117).

Third, introducing new labor laws to counter increasing labor discontent or abuses, and secure rights of workers. Introduction of new labor laws may possibly provide employers with directions to classify vital flexible working practices such as ensuring long-term employment relations between employers and employees (core or periphery). In this respect, few words on New Labor Contract Law of China can be mentioned. The Law came into force on 1st January 2008, specifying that 'employment contracts must be put in writing within one month of employment' (Zhang, 2008, p. 44) The Law restricts excessive use of temporary labors, makes harder to lay off employees, and favors long-term labor contracts instead of temporary pacts (Zhang, 2008). Therefore, workers' employment security is ensured.

Fourth, transferring specific management practice may also act to promote a win-win situation on flexibility if transfer procedure ends with effective implementation of rules prescribed in the specific practice and also persists until the prescribed rules are internalized in a transnational firm (Stehle and Erwee, 2007). An effectual implementation depends on institutionalizing the specific management practice. There are two stages of institutionalization: implementation and internalization. At the first stage, workers only pursue prescribed rules. In the second stage, workers have allegiance to the specific management practice. Ownership perception of work arrangements is also secured in the stage (Stehle and Erwee, 2007). Various macro-contextual factors such as absence of clear and stable industrial policy, existing national labor laws, traditional structure and role of government and trade unions, and market reforms initiatives to increase production and investment may possibly delay implementation of the two stages of institutionalization (Guzman, 2000). Therefore, transnational firms should be careful about the macro-contextual factors.

\subsubsection{External factors}

First, it is important to increase effective role of trade unions. Trade unions may force employers demanding better working conditions and job security for employees (Anner, 2007). A study of Pegler (2001) also supports the idea to avoid unusual labor turnover and have elongated and stable employment relations between employers and employees. On the other hand, a joint study of Pegler and Knorringa (2007) reveals that trade unions with their effective representations and collective inputs may increase production and performance of a transnational firm. Therefore, joint efforts of trade unions, workers and employers are required to have mutual gains on flexibility. While trade unions should be recognized and representative, workers should demonstrate greater adherence to trade unions and their firm.

Second, developing the role of corporate social responsibility (CSR) is vital to make flexibility a positive thing for both employers and employees (Blowfield, 1999; Barrientos et al., 2003; Shaw et al., 2006; Knorringa and Pegler, 2006). Better CSR may reasonably be promoted 'to help bolster an argument that better labor rights are good business and also to put forth trade unions that should be more significant stakeholders in CSR' (Pegler and Knorringa, 2007, p. 45). Therefore, a prime task of CSR should be 'to support ongoing struggle by workers in the developing countries and their collective action representatives, whether trade unions or NGOs, in an effort to increasingly implement decent work agenda of International Labor Organization' (Knorringa and Pegler, 2006, p. 477).

Third, enhancing the drive of ethical trading initiative, a well-recognized instance of CSR, is important. Ethical trading initiative offers an opportunity for transnational firms to work jointly with trade unions and non-government organizations to ensure whether the existing 'labor conditions meet or exceed international labor standards' (Knorringa and Pegler, 2006, p. 476). A recent joint study of Barrientos et al. (2003, p. 1518) on ethical trading reveals that 'international labor standards just profitably meet demands of core workers'. By contrast, peripheral workers' claims are variegated (Knorringa and Pegler, 2006). Therefore, the drive of ethical trading initiative should focus on developing constructive code of conduct on labor standards or conditions for both core and periphery workers.

\section{Frameworking the factors or conditions making flexibility positive for both employers and employees: a discussion}

Based on characteristics of flexibility, it is obvious that flexibility for employers is concerned with three things: $v l e, v w h$ and meiw. In other words, these three things may be the best capturing indicators of flexibility for 
employers. On the other hand, flexibility for employees is concerned with a set of things: $j s, r t, l w, w h, R s, w e$ and $m u$. In any circumstance, these notions may otherwise be the best capturing indicators of flexibility for employees.

On the basis of the indicators of flexibility for both employers and employees, the notion of flexibility for both parties in a transnational firm of a developing country behaves in a different way, sometimes positive for employers but negative for employees, and occasionally positive for both. In the variation, there could be some additional factors that may also have an impact on flexibility. For example, structure and role of government, and role of trade unions in Brazil are quite different than that in China, Malaysia and Turkey (Uddin, 2010). On the contrary, market reforms initiatives to increase level of productivity, flow of foreign direct investment, and particularly national labor laws are far different in the developing countries. Therefore, some specific factors that may make flexibility a positive thing for both employers and employees come to the fore.

If objective of achieving flexibility is through transferring any management practice, adoption of formal rules describing the transfer process and practice, and then internalization of the rules at any firm need to be prioritized. On the other hand, within the list of internal factors, changing perception of flexibility, making mutuality in work and developing trust between employers and employees, and introducing new labor laws are very important. By contrast, from the external factors, developing role of trade unions and civil society organizations (CSOs), bringing the drive of CSR to light, forcing the initiative of fair trade, ethical sourcing, and the related drives, constructive codes of conduct on labor standards, and decent work agenda of the ILO are also very crucial. The effective execution of the internal and external factors may act to promote a win-win situation on flexibility for both employers and employees.

In addition to the indicators, internal and external factors of flexibility, some general factors and challenging issues ought to effectively be taken into consideration. Employers of the transnational firms must be aware of some identified factors challenging to flexibility. Reducing institutional complexities existing in their firms is crucial. On the other hand, both employers and employees should balance their power and ownership. They could accentuate on positive social network ties. In general, employers need to change their attitude and respect to employees' basic demands. By contrast, employees' dynamic attachment with and positive response to their firms are important. Therefore, factors or conditions that may make flexibility a positive thing for both employers and employees can be framed under the following framework:

Place Figure 2 here

\section{Conclusion and recommendations}

The study concludes that $v l e, v w h$ and meiw for employers, and $j s, r t, l w, w h, R s$, we and $m u$ for employees necessitate to be addressed well to have a positive impact on flexibility. Emphasis then goes on meeting the general factors such as transferability or adaptability of a firm to introduce a new technology or technique, and HRM policies and practices such as defining labor appraisal and performance assessment method. Subsequent task is facing the factors challenging to flexibility such as accentuating on particular local and regional agglomerations of firms; removing institutional complexities; integrating relationship between firms and employees; balancing power and ownership, participation and understanding between employers and employees; increasing competence of firms and worker representations; drawing attention to contractual conformities with trade unions, and partaking rights in regards to works councils. To attain positive-sum gains on flexibility, the internal factors such as perception of flexibility, mutuality in work, trust between employers and employees, and labor laws need to be effectively developed. Simultaneously the role of unionism, CSOs, CSR, fair trade and ethical sourcing, and the ILO decent work agenda within the periphery of external factors demand to be recognized in order to make flexibility a positive thing for employers and employees.

The study is based on consultation of secondary literature that have facilitated to conceptualize or to categorize the factors of flexibility for employers and employees. The findings of the study appear to be generalized to a certain extent. But they necessitate to be replicated rather in a broader context; in particular, the findings ought to be examined in a variety of firms for various developing as well as developed countries. Therefore, a more comprehensive and updated version on the subject require field based first hand information in future.

\section{References}

Alston, L. J. (2005). The case for cases studies in political economy. The Political Economist, 12, 1-21.

Anner, M. (2007). Forging new labor activism in global commodity chains in Latin America. International Labor and Working Class History, 72, 18-41. 
Atkinson, J. (1984). Flexibility, uncertainty and manpower management. Brighton: Institute of Manpower Studies.

Atkinson, J. (1985). Flexibility: planning for an uncertain future. Manpower Policy and Practice, 1, 26-29.

Barrientos, S., Dolan, C., \& Tallontire, A. (2003). A gendered value chain approach to codes of conduct in African horticulture. World Development, 31, 1511-1526.

Blowfield, M. (1999). Ethical trade: a review of developments and issues. Third World Quarterly, 20, 753-770.

Brodsky, M. (1994). Labor market flexibility: a changing international perspective. Monthly Labor Review, 11, 53-60.

Chung, H. (2007). Flexibility for whom? a new approach in examining labor market flexibility focusing on European companies. In H. Jorgensen, \& P. K. Madsen (Eds.), Flexicurity and beyond: finding a new agenda for the European social model (pp. 243-277). Copenhagen: DJOF Publishing.

Dedoussis, V., \& Litter, C. R. (1994). Understanding the transfer of Japanese management practices: the Australian case. In T. Elger, \& C. Smith (Eds.), Global Japanization?: the transnational transformation of the labor process (pp. 175-195). London: Routledge.

Delson, Lei. (2004). Working time flexibility: two cheers for regulation, one cheer for the market. [Online] Available: http://www.boeckler.de/pdf/wsi_2004_09_arbeitszeit_delsen.pdf (November 17, 2010).

Elger, T., \& Smith, C. (1994). Global Japanization? convergence and competition in the organization of the labor process. In T. Elger, \& C. Smith (Eds.), Global Japanization?: the transnational transformation of the labor process (pp. 31-59). London: Routledge.

Gamble, J., Morris, J., \& Wilkinson, B. (2004). Mass production is alive and well: the future of work and organization in East Asia. The International Journal of Human Resource Management, 15, 397-409.

Gellatly, I. R., Hunter, K. H., Currie, L. G., \& Irving, P. G. (2009). HRM practices and organizational commitment profiles. The International Journal of Human Resource Management, 20, 869-884.

Gleave, S., \& Oliver, N. (1990). Human resource management in Japanese manufacturing companies in the UK: 5 case studies. Journal of General Management, 16.

Graham, L. (1994). How does the Japanese model transfer to the United States? a view from the line. In T. Elger, \& C. Smith (Eds.), Global Japanization?: the transnational transformation of the labor process (pp. 123-151). London: Routledge.

Guzman, G. A. C. (2000). New production system in transition: implications for the Brazilian industry. Brazilian Journal of Political Economy, 20, 48-67.

Houseman, S. N. (2001). Why employers use flexible staffing arrangements: evidence from an establishment survey. Industrial and Labor Relations Review, 55.

Humphrey, J. (1994). Japanese methods and the changing position of direct production workers: evidence from Brazil. In T. Elger, \& C. Smith (Eds.), Global Japanization?: the transnational transformation of the labor process (pp. 327-347). London: Routledge.

Hunter, L., McGregor, A., Maclnnes, J., \& Sproull, A. (1993). The ‘flexible firm': strategy and segmentation. British Journal of Industrial Relations, 31, 383-407.

Kalleberg, A. L. (2003). Flexible firms and labor market segmentation: effects of workplace restructuring on jobs and workers. Work and Occupations, 30, 154-174.

Ketkar, S., \& Sett, P. K. (2009). HR flexibility and farm performance: analysis of a multi-level causal model. The International Journal of Human Resource Management, 20, 1009-1038.

Knorringa, P., \& Pegler, L. (2006). Globalization, firm upgrading and impacts on labor. Journal of Economic and Social Geography, 97, 470-479.

MacInnes, J. (1987). Thatcherism at Work: Industrial Relations and Economic Change. (1st ed.). Milton Keynes: Open University Press.

Martin, S. B. (2001). Network ties and labor flexibility in Brazil and Mexico: a tale of two automobile factories. In C. Candland, \& R. Sil (Eds.), The politics of labor in a global age: continuity and change in late-industrializing and post-socialist economies (pp. 95-131). Oxford: Oxford University Press. 
Michie, J., \& Sheehan-Quinn, M. (2001). Labor market flexibility, human resource management and corporate performance. British Journal of Management, 12, 287-306.

Pegler, L. (2001). Employer 'dependence' and worker 'allegiance' within the factory of the future: evidence from Brazil. Working paper 17, School for Social Sciences, Cardiff University, 2-19.

Pegler, L., \& Knorringa, P. (2007). Integrating labor issues in global value chain analysis: exploring implications for labor research and unions. In V. Schmidt (Ed.), Trade union responses: a review by the global union research network (pp. 35-49). Geneva: International Labor Office.

Pollert, A. (1987). The flexible firm: a model in search of reality (or a policy in search of a practice?). Warwick Papers in industrial relations 19, Warwick University.

Pollert, A. (1991). The orthodoxy of flexibility. In A. Pollert (Ed.), Farewell to flexibility? (pp. 3-31). Oxford: Basil Blackwell.

Pudelko, M. (2005). Cross-national learning from best practice and the convergence-divergence debate in HRM. The International Journal of Human Resource Management, 16, 2045-2074.

Purcell, W., Nicholas, S., Merrett, D., \& Whitwell, G. (1999). The transfer of human resource and management practice by Japanese multinationals to Australia: do industry, size and experience matter? The International Journal of Human Resource Management, 10, 72-88.

Reilly, P. (2001). Types and incidence of flexibility. Flexibility at work: balancing the interests of employer and employee (pp. 33 -117). Hampshire: Gower Publishing Limited, (Chapter 4).

Rinehart, J., Robertson, D., Huxley, C., \& Wareham, J. (1994). Reunifying conception and execution of work under Japanese production management? a Canadian case study. In T. Elger, \& C. Smith (Eds.), Global Japanization?: the transnational transformation of the labor process (pp. 152-174). London: Routledge.

Shaw, D., Newholm, T., \& Dickinson, R. (2006). Consumption as voting: an exploration of consumer empowerment. European Journal of Marketing, 40, 1049-1067.

Smith, A. E. (1995). The flexible firm: strategy or structure? Research and Practice in Human Resource Management, 3, 85-96.

Stehle, W., \& Erwee, R. (2007). Transfer of human resources practices from German multinational enterprises to Asian subsidiaries. Research and Practices in Human Resources Management, 15, 63-68.

Tayeb, M. (1998). Transfer of HRM practices across cultures: an American company in Scotland. The International Journal of Human Resource Management, 9, 332-357.

Taylor, B., Elger, T., \& Fairbrother, P. (1994). Transplants and emulators: the fate of the Japanese model in British electronics. In T. Elger, \& C. Smith (Eds.), Global Japanization?: the transnational transformation of the labor process (pp. 196-228). London: Routledge.

Tikos, Stathis. (2009). Wage flexibility: the case of Greece. [Online] Available: http://www.eurofound.europa.eu/eiro/studies/tn0803019s/gr0803019q.htm (August 3, 2009)

Toledo, E. de la G. (2007). The crisis of the Maquiladora model in Mexico. Work and Occupation, 34, 399-429.

Uddin, M. J. (2010). Flexibility of what and for whom? BIISS Journal, 31, 101-125.

Walby, S. (1989). Flexibility and the changing sexual division of labor. In S. Wood (Ed.), the transformation of work? (pp. 1-43). London: Unwin Hyman Ltd.

Wood, S. (1989). The transformation of work? (1st ed.). London: Unwin Hyman Ltd, (Chapter 1).

Yanadon, Y., \& Kato, T. (2009). Work and family practices in Japanese firms: their scope, nature and impact on employee turnover. The International Journal of Human Resource Management, 20, 439-456.

Zhang, L. (2008). Lean production and labor controls in the Chinese automobile industry in an age of globalization. International Labor and Working Class History, 73, 24-44. 


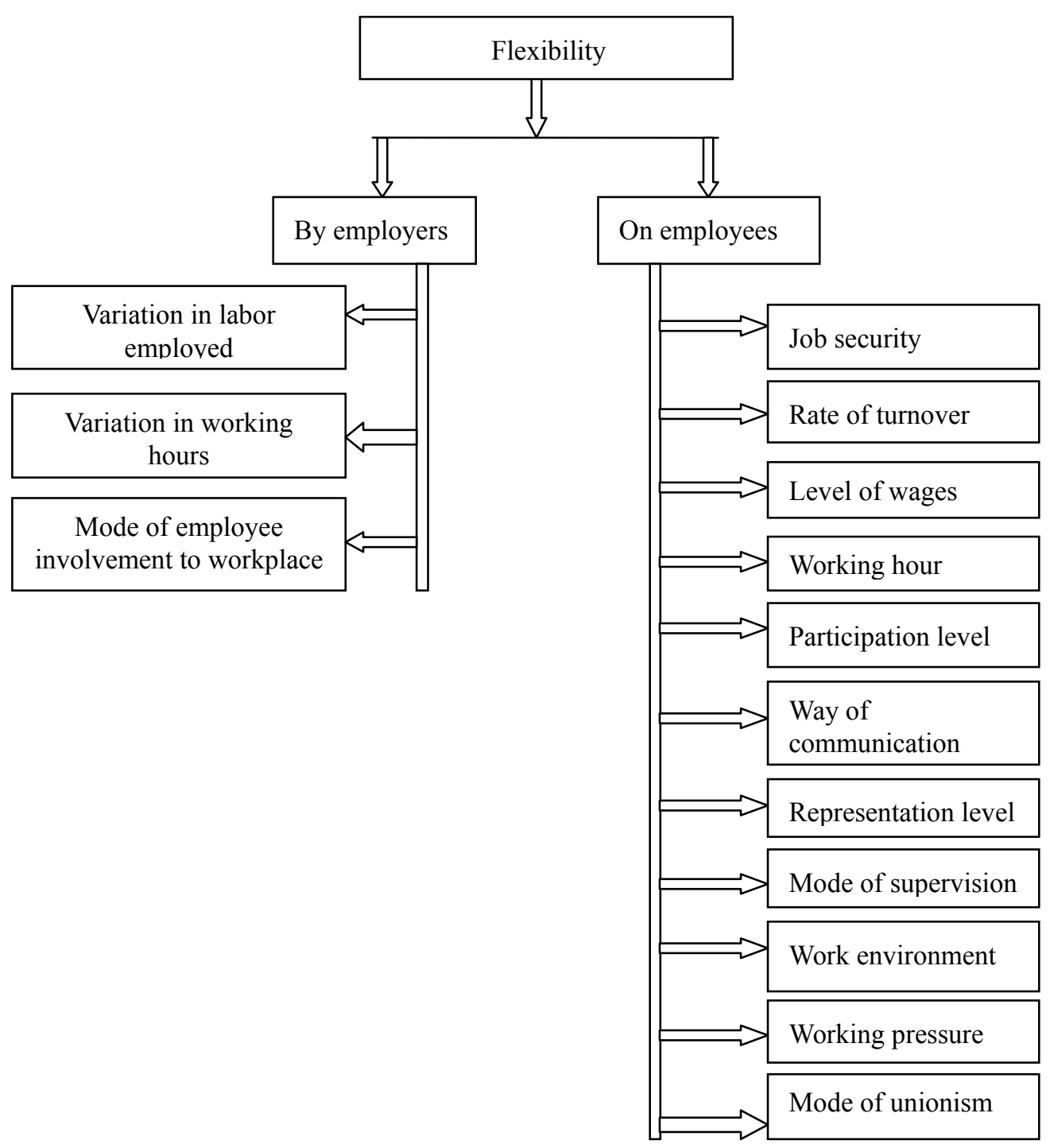

Figure 1. Best capturing indicators of flexibility for employers and employees

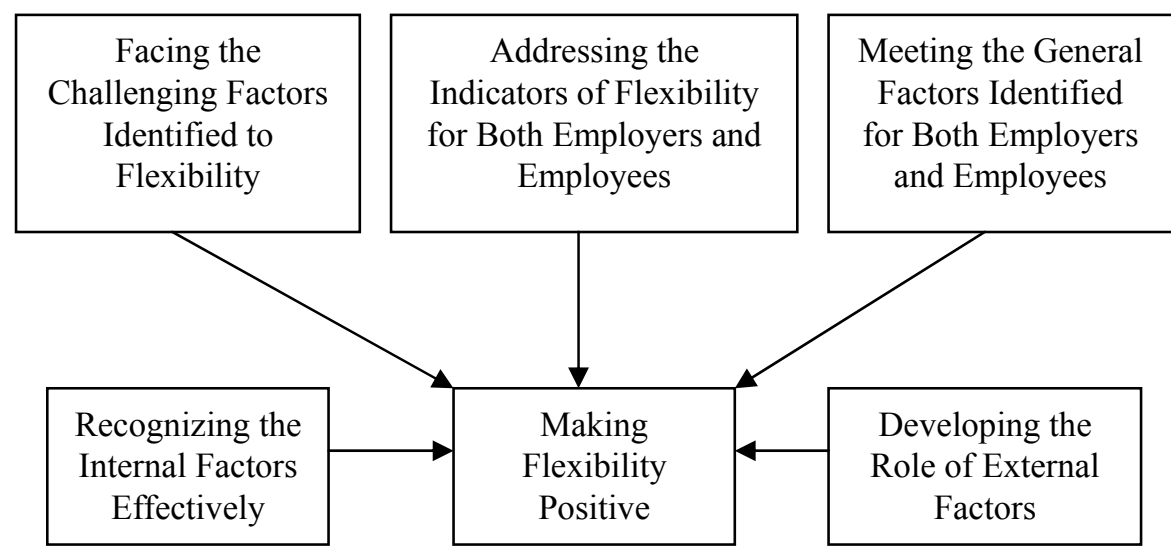

Figure 2. Frameworking the factors making flexibility positive 